F. Fiorillo, P. Revellino, and G. Ventafridda - Karst aquifer draining during dry periods. Journal of Cave and Karst Studies, v. 74, no. 2, p. 148-156. DOI: $10.4311 / 2011$ JCKS0207

\title{
KARST AQUIFER DRAINING DURING DRY PERIODS
}

\author{
Francesco Fiorillo', Paola Revellino', and Gerardo Ventafridda²
}

\begin{abstract}
We analyzed hydrographs of five karst springs in southern Italy during the recession period using ten continuous years of daily discharge measurements and provided conclusions on the aquifer behavior under dry periods and droughts. A straight line was fitted to a semilogarithmic plot (log-discharge versus time), and the recession coefficient (the slope of the line generated from the equation) was calculated for each spring and for each year considered. A deviation from the straight line produced by a simple exponential decay of discharge through time provides information on the actual emptying rate of the aquifer compared to a simple exponential decline. If the recession coefficient decreases or increases, the aquifer is empting more slowly or more quickly than expected, respectively. Water level of a monitored well inside the karst catchment was also assessed and provided information on the water distribution into aquifers. The results describe the hydraulic behavior of karst aquifers during their emptying and provide information for better management of karst springs.
\end{abstract}

\section{INTRODUCTION}

Karst aquifers have a fundamental importance for water supply, and large springs are often exploited for commercial and public water supplies (White, 1988; Bakalowicz, 2005; Ford and William, 2007; Goldscheider and Drew, 2007). Spring-discharge data are often used to describe the hydraulic behavior of karst aquifers, especially when other hydrogeological data are missing; in particular, the analysis of spring hydrographs provides information on water storage and the distribution of discharge through time.

The shape of spring hydrographs is controlled by the hydrogeological setting of the catchment area and climate characteristics. Criss and Winston (2003) proposed a simple analytical model to simulate the entire spring hydrograph of small basins and karst springs. During the period of no recharge, spring discharge decreases until the following recharge event. In particular, during the dry season spring hydrographs show a continuous decreasing trend that is know as a recession limb; the nearly flat part at the end of the recession limb is known as baseflow. The traditional approach of recession limb analysis is carried out by using the Maillet formula:

$$
Q(t)=Q_{0} e^{-\alpha\left(t-t_{0}\right)},
$$

where $Q_{0}$ is the spring discharge at the beginning of the recession $\left(t=t_{0}\right)$, and $\alpha$ is the recession coefficient with dimension $\left[\mathrm{T}^{-1}\right]$. The recession coefficient is found by plotting the data in a semilogarithmic plot; Equation (1) appears as a straight line with a constant slope independent of the initial $Q_{0}$ value (Fig. 1a). Equation (1) is that of a linear reservoir without recharge, where the discharge is proportional at any time to the water volume stored.

Real examples of the recession limb of karst spring hydrographs in the semilogarithmic plot have shown a variation in the angle of the straight line; this indicates the presence of more than one recession coefficient during the entire recession period (Forkasiewicz and Paloc, 1967; Milanovic, 1976; Atkinson, 1977).

An important purpose of karst water management is to assess the behavior of springs under drought conditions that induce a continuous decrease of the discharge, thereby extending the recession limb and providing additional, different recession-coefficient values. A recent editorial (Goldscheider and Ravbar, 2010) highlights the importance of climate change and droughts in future karst hydrogeology research.

Figure $1 \mathrm{~b}$ shows three main different shapes of the recession limb: Curve 1 shows a simple exponential decrease (Equation (1)), and curves 2 and 3 are characterized by decreasing or increasing recession coefficients during the emptying process. Curve 2 indicates that the discharge decreases more slowly than the simple exponential decay; this behavior of a spring and aquifer system produces the most reliable water supply and is preferable during long dry periods, especially in the Mediterranean area, which is characterized by long and hot dry seasons. Curve 3 indicates that discharge decreases faster than simple exponential decay; this behavior of a spring and aquifer system can cause discharge to fall too quickly during the dry season or under drought conditions, and provides difficult conditions for water management.

Fiorillo (2011) provides a hydrogeological model explaining the behavior of the karst aquifer during emptying and also discusses other models that predict the shape of the spring hydrograph in the semilogarithmic plot, such as those of Forkasiewicz and Paloc (1967), Mangin (1975), Kovacs et al. (2005), and Kovács and Perrochet (2008).

\footnotetext{
${ }^{1}$ Dipartimento di Scienze per la Biologia, Geologia e l'Ambiente, University of Sannio, via dei Mulini 59/A, Benevento, Italy, francesco.fiorillo@unisannio.it ${ }^{2}$ Acquedotto Pugliese, Direzione Industriale, viale Orlando 1, Bari, Italy, g.ventafridda@aqp.it
} 

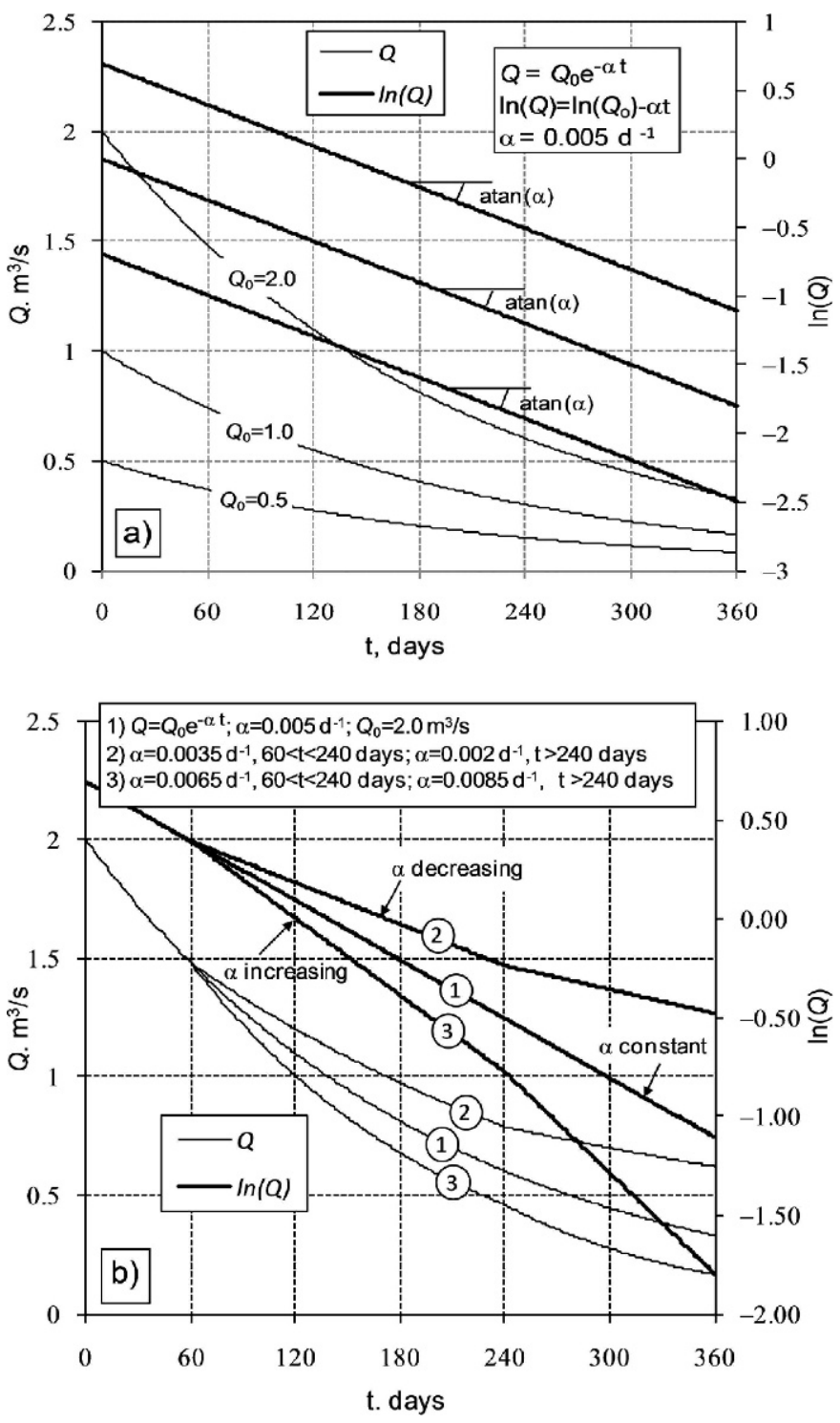

Figure 1. Arithmetic and logarithmic plots of: a) exponential function of Maillet for different initial values of $Q_{0}$; b) constant (curve 1) and non-constant (curve 2 and 3) recession coefficient value $\alpha$ during emptying.

On the basis of Fiorillo's model (2011), we analyze daily discharge measurements of karst springs located in Campania, southern Italy: the Caposele springs and the Cassano Irpino springs, plus two individual springs in the Cassano group. We also discuss the monitoring of a well inside the karst catchment that allowed us to check Fiorillo's (2011) model.

\section{HydRogeologicAl AND Hydrological Characteristics}

The Picentini Mountains constitute a large $600 \mathrm{~km}^{2}$ karst system in the Campania region of southern Italy
(Fig. 2). In the northeastern sector, over $70 \%$ of the catchment lies above $1,000 \mathrm{~m}$ a.s.l., up to the top of Mt. Cervialto $(1,809 \mathrm{~m}$ a.s.1.). In the northwestern sector, $30 \%$ of the catchment lies above 1,000 m a.s.l., with the highest point being the top of Mt. Terminio (1,806 $\mathrm{m}$ a.s.1.).

Wide areas of closed depressions, such as the Piana del Dragone and Lago Laceno, located inside the Terminio and Cervialto massifs, respectively, favor the infiltration processes.

Outcropping rocks in the area primarily belong to calcareous and calcareous-dolomitic series of the Late Triassic through the Miocene; they are 2,500 m thick, heavily fractured and faulted, and frequently reduced to breccias. The slopes are generally mantled by pyroclastic deposits of Somma-Vesuvius activity, which play an important role in the infiltration of water into the karst substratum below. The calcareous-dolomite series are tectonically bounded by terrigenous and impermeable deposits comprising complex argillaceous (Paleocene) and flysch sequences (Miocene). Further details of geological features of the Southern Apennine can be found in the Geological Map of Italy (1:50,000 scale; ISPRA, 2009).

The region is located in an area with a typical Mediterranean climate characterized by dry, warm summers and a wet period that occurs during autumn, winter, and spring. The monthly rainfall reaches a maximum during November and a minimum in July (Fig. 3). The pattern of potential evapotranspiration, computed using the method described by Thornthwaite (1948), was found to be almost completely opposite to that of rainfall, reaching a maximum in July and a minimum in December-February.

The large springs of the Picentini Mountains belong to three main groups, known as the Serino, Cassano Irpino, and Caposele springs (Fig. 2c). Minor springs are located along the northern boundary of the Mt. Tuoro, in the northern sector of the Terminio massif.

In this study we focus the analysis on the Cassano Irpino and Caposele groups that feed the Acquedotto Pugliese S.p.A., the main aqueduct system in Italy. It supplies water to the Puglia region through a gravity channel about $400 \mathrm{~km}$ long. The Caposele group is formed by Sanità Spring $(417 \mathrm{~m}$ a.s.l.) and several minor springs, all located at the head of the Sele River basin along the northeastern boundary of the Picentini Mountains. The Sanità Spring is fed by the Cervialto karst massif (Celico and Civita, 1976), has a mean annual discharge of $3.96 \mathrm{~m}^{3} \mathrm{~s}^{-1}$ (period 1920-2009), and was tapped in 1920. The Cassano group is located in the Calore River basin along the northern boundary of the Picentini Mountains and consists of the Bagno della Regina, Peschiera, Pollentina, and Prete springs (473 to $476 \mathrm{~m}$ a.s.1.). These springs are primarily fed by the TerminioTuoro (Coppola et al., 1989) massif and have an overall mean annual discharge of $2.65 \mathrm{~m}^{3} \mathrm{~s}^{-1}$ (period 1965-2009). The Peschiera and Prete spring discharges oscillate slightly during the year, whereas the Pollentina and Bagno della Regina discharges strongly reflect the rainfall regime.

Journal of Cave and Karst Studies, August 2012•149 

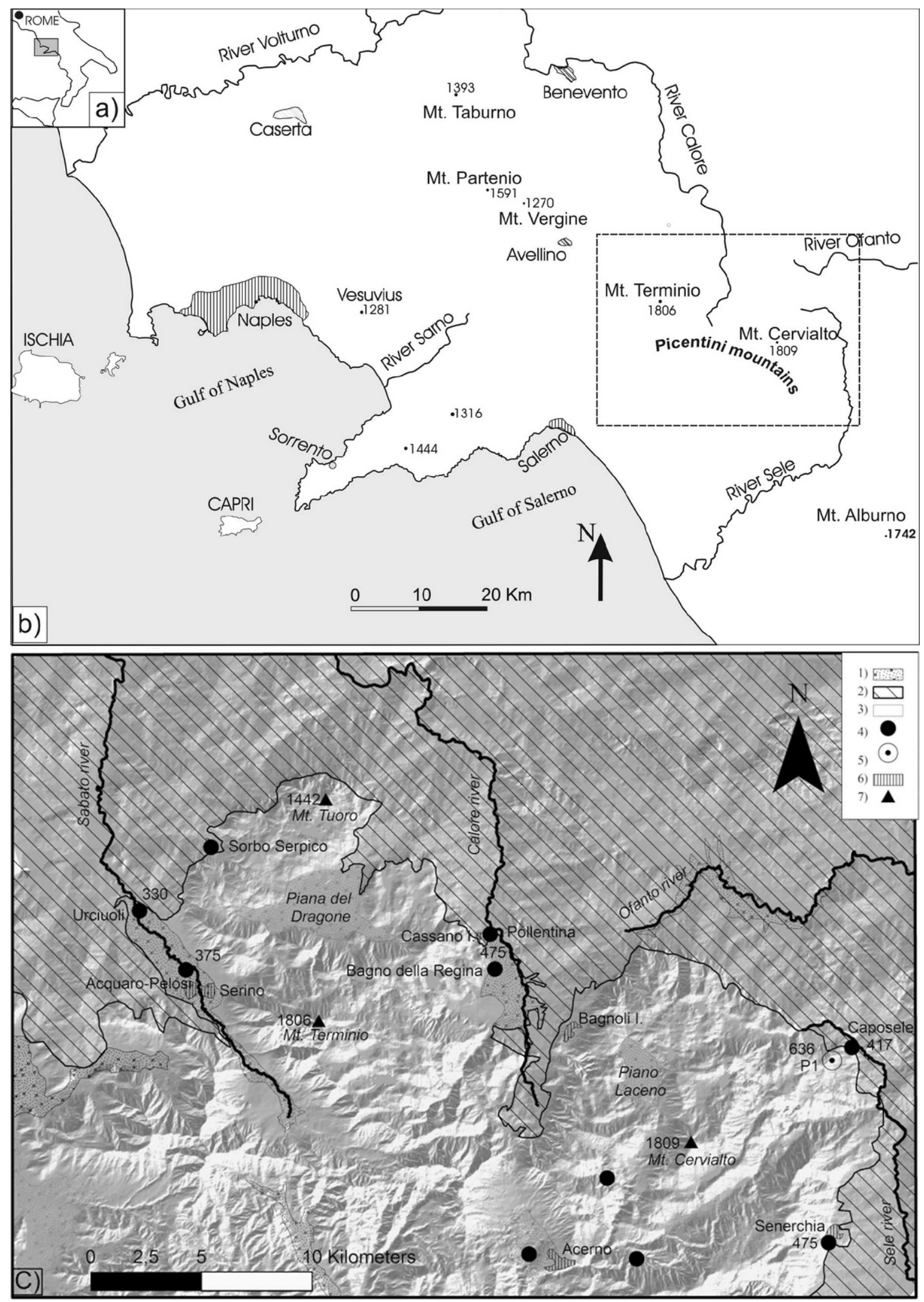

Figure 2. a) Southern Italian peninsula. b) Map of the western Campania region. c) Hydrogeological features of the northern Picentini Mountains outlined in part b. Key: 1) slope breccias and debris, pyroclastic, alluvial, and lacustrine deposits (Quaternary); 2) argillaceous complex and flysch sequences (Paleogene-Miocene); 3) calcareous-dolomite series (Mesozoic); 4) major spring; 5) P1 well; 6) village; 7) mountain peak. 


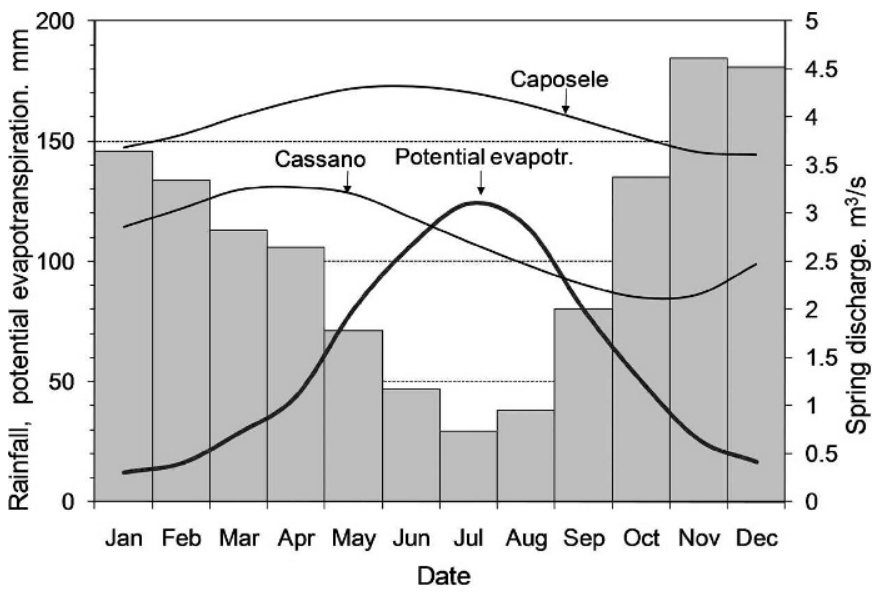

Figure 3. The bars show the mean monthly rainfall and a curve shows the potential evapotranspiration, averages of stations at the Serino (351 m a.s.l.), Cassano (450 m a.s.l.), and Caposele (430 $\mathrm{m}$ a.s.l.) springs. Additional curves show the mean discharges of the Caposele and Cassano. Data period is 1921-2006, except Cassano spring discharge, 19662006 (modified from Fiorillo, 2009).

The daily spring discharge data cover a 10 -year period (January 1, 2000 through December 31, 2009) (Fig. 4). During this period, hydrographs of the wet years are characterized by well-pronounced floods during the spring season, as occurred in 2000, 2006, and 2009, whereas hydrographs of dry years are characterized by slight floods or a continuously decreasing discharge trend during the hydrological year (Fiorillo, 2009). In particular, 2001/02 was one of the most intense hydrological droughts that occurred in southern Italy (Fiorillo and Guadagno, 2010) and caused the historical minimum discharge in many karst springs. After the dry years of 2006/ 07 and 2007/08, the annual rainfall of the 2008/09 was one of the highest of the historical series, and increased the spring discharges much more than the mean.

Recharge regularly occurs during the autumn-winter season and causes the maximum spring discharge during the spring; during the spring-summer season, due to the high rate of evapotranspiration, recharge can be considered null (Fiorillo et al., 2007; Fiorillo, 2009). Single rain events (daily rainfall) have no direct influence on the spring discharge, and spring hydrographs are characterized by little or no prompt flow, due to a poor development or connection of the karst conduits (Fiorillo 2009). The spring discharge depends on the long term cumulative rainfall; in particular, Fiorillo and Doglioni (2010) analyzed the relation between rainfall and spring discharge by crosscorrelation analyses and found that Caposele springs' discharge is shifted up to several months with respect to rainfall and depends mainly on the rainfall accumulated over the preceding 270 days.

\section{Analysis of the Aquifer Draining}

Spring discharge data were analyzed to focus on the summer to early-autumn period, during which time a continuous decreasing discharge trend is generally observed and the recharge processes can be considered negligible. During this period, spring hydrographs present a concave shape that follow the previous convex shape connected to the peak or flood earlier in the year.

To evaluate the recession coefficient of the springs, daily discharge data of each hydrological year were plotted in a semilogarithmic graph. Figure 5 shows the case of the Caposele springs, where the plotted period starts generally on September 1 and ends October 31 (61 days); only 2002 starts on April 6 and ends on June 6, because nolinear correlation has been found for the period September 1 to October 31. Table 1 shows the results of all springs. For all the Cassano Irpino group of springs and its individual components Pollentina Spring and the Bagno della Regina spring, the recession coefficients have been computed during the period July 1 to August 31 (62 days). As can be observed from the examples in Figure 5, each plot appears as a straight line, indicating that the aquifer behaves as a linear reservoir without recharge (Equation (1)). However, the

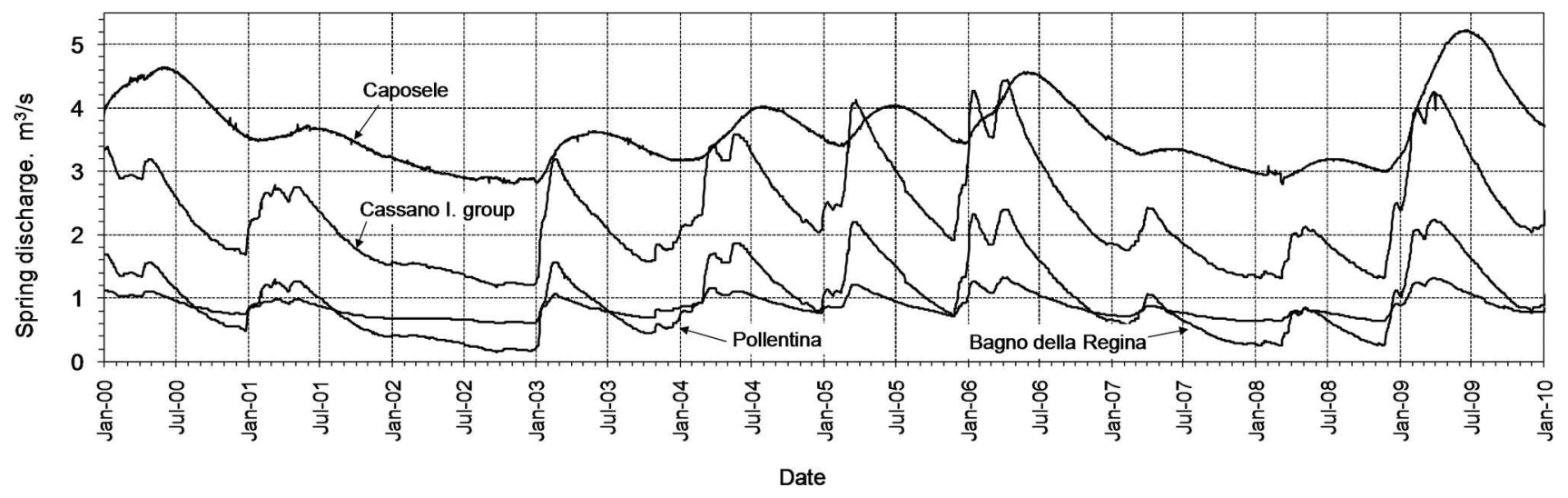

Figure 4. Daily spring discharge data from January 1, 2000, through December 31, 2009. These are totals for the Caposele and Cassano spring groups and individual records for the two major members of the Cassano group. 


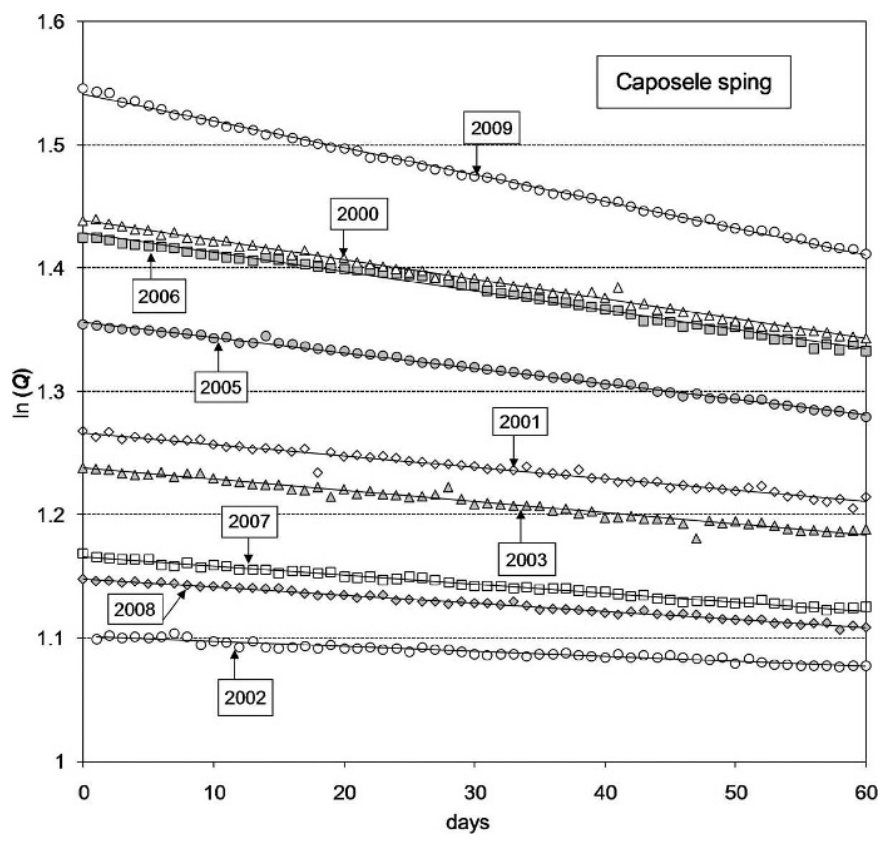

Figure 5. Natural logarithms of the Caposele group daily discharges during linear periods. Day 0 is September 1 for 2000-2009 and April 6 for 2002; no data are shown for 2004.

slope of the linear fit (the recession coefficient) changes from one year to another, indicating a dependence on the initial condition of the aquifer, and in particular, on the spring discharge at the beginning of the draining, $Q_{0}$ (Fig. 6). The Caposele group and Pollentina Spring show a linear and positive relationship between $\alpha$ and $Q_{0}$ (Figure 6); for these springs the recession coefficient is smaller during droughts and higher after wet years. On the other hand, the Bagno della Regina spring shows a negative relationship between $\alpha$ and $Q_{0}$. Over a longer period, the tail of the recession curve for the Caposele and Pollentina springs behaves like curve 2 in Figure 1b, showing a decrease of the recession coefficient during the aquifer emptying. The Bagno della Regina spring is different from the Caposele and Pollentina springs, as it shows the discharge decrease similar to curve 3 of Figure $1 \mathrm{~b}$. In all cases, a single recession coefficient value seems unable to explain all the draining processes of the aquifer.

The different behaviors can also be observed by plotting the frequency distribution of the daily data (Fig. 7), where the distributions for Pollentina Spring and the Caposele group cut off abruptly and never reach low values, whereas the Bagno della Regina spring distribution shows the possibility of reaching a null spring discharge under intense drought.

The Bagno della Regina and Pollentina springs are very close together (Fig. 2c) and have similar elevations, and the two smaller springs, Prete and Peschiera, in the Cassano group are located close to Pollentina. This and the other results suggest that all these springs are fed by the same groundwater system and during the draining of the aquifer, interference among these springs occurs, so the analyses should be conducted considering the sum of the discharge of all four springs, as the Cassano spring group, in Figures 2 and 6 and Table 1. In addition, the same groundwater system feeds other karst springs located along the northern (Sorbo Serpico springs) and western (Serino springs) boundary of the Terminio-Tuoro massif (Fig. 2c), indicating further interferences during the draining of the aquifer.

The Caposele springs are the only major springs draining the wide catchment of $\mathrm{Mt}$. Cervialto. The minor springs in the basin drain only a few liters per second. Therefore, during the draining of the aquifer, a constant water table area can be considered for the Caposele springs, which helps to explain the simple variation of the recession coefficient during the draining of different years. A useful water level dataset comes from a well located at $635.54 \mathrm{~m}$ a.s.l. inside the catchment of the Caposele group (P1, Fig. 2c). The available data are shown in Figure 8a, for the dry year of 2008 and the wet year of 2009, which are characterized by very different initial conditions of $Q_{0}$ (Table 1). During October 2009, the decrease in the water level in the P1 well was $0.32 \mathrm{~m}$ and the volume discharged by the Caposele springs was $11.3 \times 10^{6} \mathrm{~m}^{3}$ (Figure 8b). During October 2008 the decrease of the water level into well was $0.06 \mathrm{~m}$, and the volume discharged by the Caposele springs was $8.2 \times 10^{6} \mathrm{~m}^{3}$ (Figure 8b). A different behavior can be observed during these two periods: In October 2008 the aquifer discharged a water volume of $V_{w(2008)}=1.37 \times 10^{6} \mathrm{~m}^{3}$ for each centimeter of well level lowering, and in October 2009 the water volume discharged was $V_{w(2009)}=0.35 \times 10^{6} \mathrm{~m}^{3}$ (Figure $8 \mathrm{~b}$ ). This different hydraulic behavior suggests that the storage conditions increase in depth; in particular, the effective porosity, $n_{\text {eff }}$, has to increase from the high to low water table level, inside the epiphreatic zone. The ratio between these two values could be compared with the ratio of the effective porosity values:

$$
\frac{n_{\text {eff }(2008)}}{n_{\text {eff }(2009)}} \approx \frac{V_{w(2008)}}{V_{w(2009)}}=\frac{1.37 \times 10^{6}}{0.35 \times 10^{6}}=3.91 .
$$

This assumes that in the unconfined aquifer the storativity can be approximated by the effective porosity, and its use in the karst aquifer has been discussed by Stevanovic et al. (2010).

During the draining of the karst aquifer, the model of Fiorillo (2011) shows how the variation of the recession coefficient, for example from $\alpha^{\mathrm{II}}$ to $\alpha^{\mathrm{III}}$, with $\alpha^{\mathrm{II}}>\alpha^{\mathrm{III}}$, can be approximated by the change of the effective porosity, from $n_{\text {eff }}^{I I} \rightarrow n_{\text {eff }}^{I I I}$, with $n_{\text {eff }}^{I I}<n_{\text {eff }}^{I I I}$, by the following (Fiorillo, 2011):

$$
\frac{\alpha^{I I}}{\alpha^{I I I}} \approx \frac{n_{e f f}^{I I I}}{n_{\text {eff }}^{I I}},
$$

which is valid only for a constant water table area during the draining. In this case, Equation (3) gives

$$
\frac{n_{\text {eff }(2008)}}{n_{\text {eff }(2009)}} \approx \frac{\alpha_{(2009)}}{\alpha_{(2008)}}=\frac{0.00230}{0.00060}=3.83 .
$$


F. Fiorillo, P. Revellino, and G. Ventafridda

Table 1. Values deduced from the semilogarithmic plots during linear periods for the Caposele and Cassano spring groups and two component springs of the Cassano group.

\begin{tabular}{|c|c|c|c|c|c|c|}
\hline Spring & Year & $\alpha, \mathrm{d}^{-1}$ & $R^{2}$ & $\ln \left(Q_{0}\right)$ & $Q_{0}, \mathrm{~m}^{3} \mathrm{~s}^{-1}$ & $t_{1 / 2}, \mathrm{y}$ \\
\hline \multicolumn{7}{|c|}{ Caposele } \\
\hline & 2000 & 0.0016 & 0.995 & 1.438 & 4.21 & 1.19 \\
\hline & 2001 & 0.0009 & 0.971 & 1.266 & 3.55 & 2.11 \\
\hline & 2002 & 0.0004 & 0.984 & 1.101 & 3.01 & 4.75 \\
\hline & 2003 & 0.0009 & 0.967 & 1.237 & 3.45 & 2.11 \\
\hline & 2004 & 0.0012 & 0.989 & 1.358 & 3.89 & 1.58 \\
\hline & 2005 & 0.0013 & 0.996 & 1.357 & 3.88 & 1.46 \\
\hline & 2006 & 0.0016 & 0.989 & 1.429 & 4.17 & 1.19 \\
\hline & 2007 & 0.0007 & 0.987 & 1.162 & 3.2 & 2.71 \\
\hline & 2008 & 0.0006 & 0.988 & 1.165 & 3.21 & 3.17 \\
\hline & 2009 & 0.0023 & 0.997 & 1.540 & 4.66 & 0.83 \\
\hline \multicolumn{7}{|c|}{ Bagno della Regina } \\
\hline & 2000 & 0.0057 & 0.997 & 0.466 & 1.59 & 0.33 \\
\hline & 2001 & 0.0058 & 0.996 & 0.163 & 1.18 & 0.33 \\
\hline & 2002 & 0.0062 & 0.987 & -1.145 & 0.32 & 0.31 \\
\hline & 2003 & 0.0063 & 0.997 & 0.035 & 1.04 & 0.3 \\
\hline & 2004 & 0.0044 & 0.997 & 0.633 & 1.88 & 0.43 \\
\hline & 2005 & 0.0051 & 0.991 & 0.539 & 1.71 & 0.37 \\
\hline & 2006 & 0.0050 & 0.997 & 0.609 & 1.84 & 0.38 \\
\hline & 2007 & 0.0061 & 0.988 & 0.255 & 1.29 & 0.31 \\
\hline & 2008 & 0.0065 & 0.996 & 0.254 & 1.29 & 0.29 \\
\hline & 2009 & 0.0050 & 0.997 & 0.624 & 1.87 & 0.38 \\
\hline \multicolumn{7}{|c|}{ Pollentina } \\
\hline & 2000 & 0.0021 & 0.978 & 0.018 & 1.02 & 0.90 \\
\hline & 2001 & 0.0020 & 0.994 & 0.078 & 1.08 & 0.95 \\
\hline & 2002 & 0.0008 & 0.885 & -0.407 & 0.67 & 2.37 \\
\hline & 2003 & 0.0016 & 0.979 & -0.191 & 0.83 & 1.19 \\
\hline & 2004 & 0.0022 & 0.995 & 0.109 & 1.12 & 0.86 \\
\hline & 2005 & 0.0021 & 0.987 & 0.008 & 1.01 & 0.90 \\
\hline & 2006 & 0.0024 & 0.994 & 0.117 & 1.12 & 0.79 \\
\hline & 2007 & 0.0015 & 0.992 & -0.235 & 0.79 & 1.27 \\
\hline & 2008 & 0.0016 & 0.995 & -0.222 & 0.80 & 1.19 \\
\hline & 2009 & 0.0029 & 0.982 & 0.134 & 1.14 & 0.65 \\
\hline \multicolumn{7}{|c|}{ Cassano I. Group } \\
\hline & 2000 & 0.0034 & 0.995 & 1.047 & 2.849 & 0.56 \\
\hline & 2001 & 0.0030 & 0.998 & 0.946 & 2.575 & 0.63 \\
\hline & 2002 & 0.0016 & 0.934 & 0.357 & 1.428 & 1.19 \\
\hline & 2003 & 0.0031 & 0.996 & 0.826 & 2.284 & 0.61 \\
\hline & 2004 & 0.0031 & 0.997 & 1.281 & 3.60 & 0.61 \\
\hline & 2005 & 0.0033 & 0.993 & 1.190 & 3.287 & 0.57 \\
\hline & 2006 & 0.0034 & 0.999 & 1.253 & 3.50 & 0.56 \\
\hline & 2007 & 0.0027 & 0.997 & 0.700 & 2.014 & 0.70 \\
\hline & 2008 & 0.0029 & 0.997 & 0.701 & 2.015 & 0.65 \\
\hline & 2009 & 0.0036 & 0.998 & 1.275 & 3.579 & 0.53 \\
\hline
\end{tabular}

$\alpha=$ recession coefficient; $R^{2}=$ coefficient of determination; $Q_{0}=$ spring discharge at time $t=0$; and $t_{1 / 2}=$ half-time of the spring discharge.

Equations (2) and (4) calculate the effective porosity ratio by different approaches, but indicate that the two values are very close, verifying that Equation (3) is well founded.

\section{Discussion AND CONCLUSIONS}

Based on the shape of the spring hydrograph during the recession period and, in particular, on the value of the 


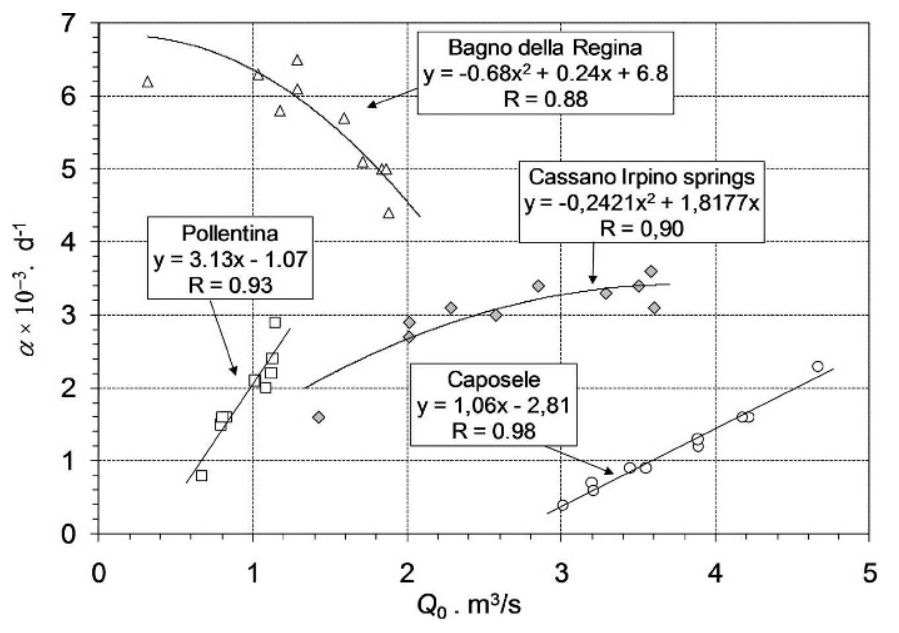

Figure 6. Relation between the recession coefficient $\alpha$ and spring discharge at the beginning of the draining $Q_{0}$ for the years 2000-2009 (Table 1). The Bagno della Regina spring and Rollentina Spring are components of the Cassano Irpino group. recession coefficient, the hydraulic behavior of the aquifer can be outlined during dry periods and droughts.

If spring discharge decreases following the exponential decay (linear reservoir) model, a single value of the recession coefficient $\alpha$ is able to explain the entire draining of the aquifer. This condition appears to be rare in nature, especially under drought conditions, which provide the possibility to investigate the lowest part of the recession limb of spring hydrographs. Under such conditions, hydrographs tend to be as curve 2 or 3 of Figure $1 \mathrm{~b}$, indicating non-constant $\alpha$ during the emptying. Many karst springs show a typical variation of the recession coefficient during aquifer draining, especially if several continuous years are considered, including droughts. Fiorillo (2011) has explained that the variation in the recession coefficient is due to non-constant geometric or hydraulic characteristics during the emptying process. In particular, the recession coefficient appears to be strongly controlled by the product of the effective porosity along the water table
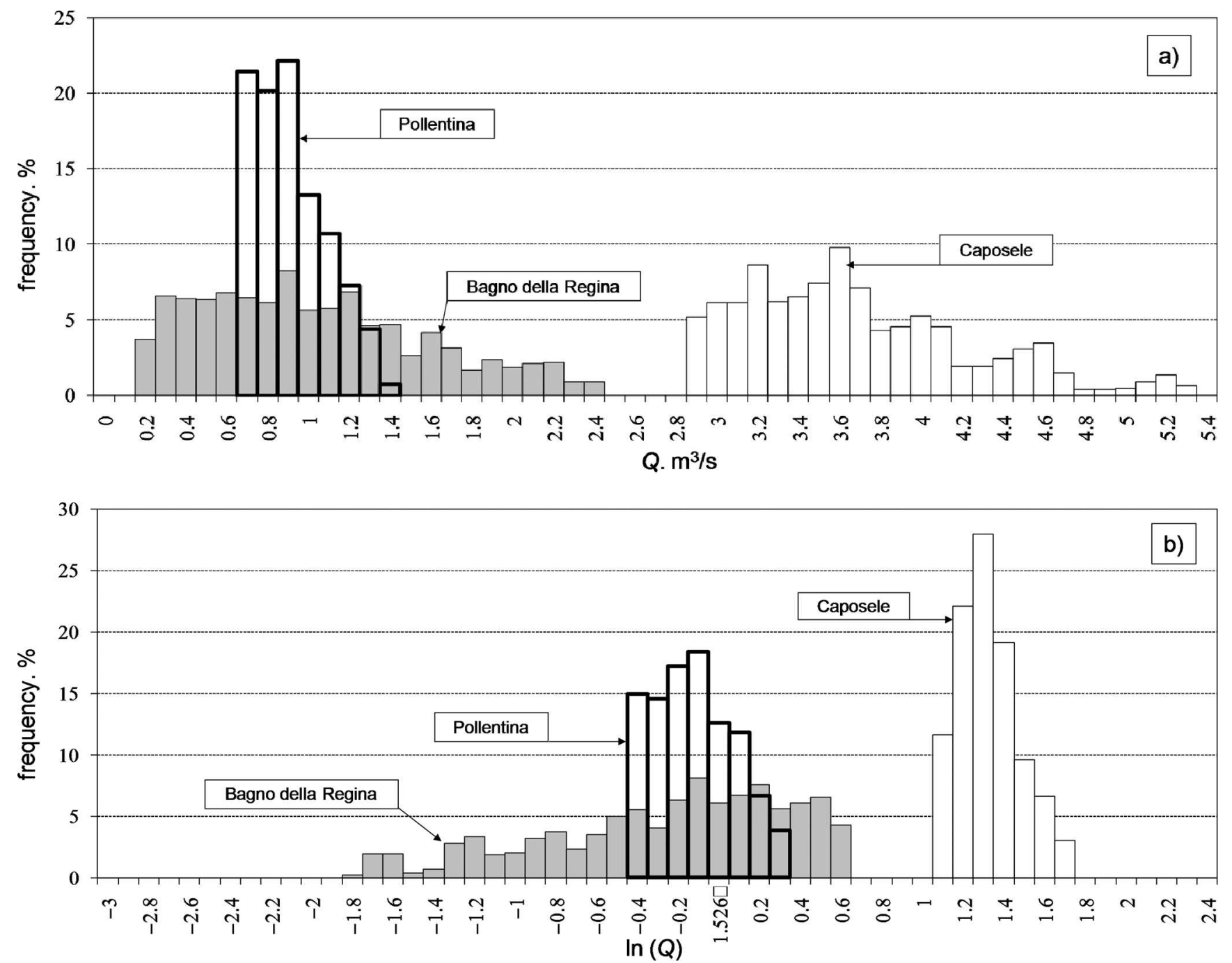

Figure 7. Spring discharge frequency distributions for the Caposele and the two major springs in the Cassano group, period January 1, 2000, through December 31, 2009: a) normal plot, b) logarithm plot. 

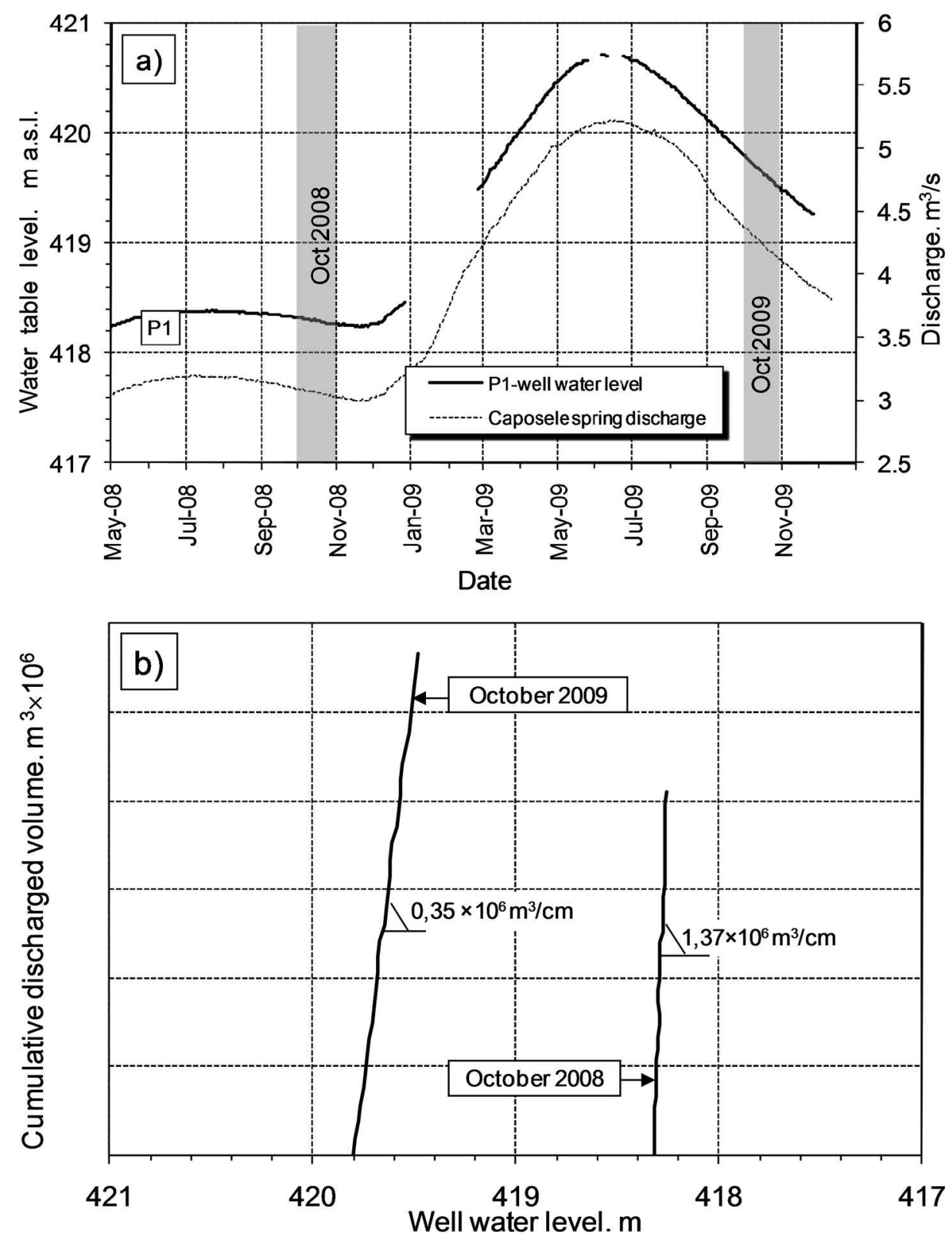

Figure 8. a) Caposele spring discharge and water level monitored in well P1, May 1, 2008, through November 30, 2009. b) Total discharged water volume in relation to the level in the well P1, during the periods October 2008 and October 2009 , based on the data in part a. (Note that the horizontal axis is reversed.) The calculated water volume per centimeter of lowering is shown.

and the area occupied by the water table. This product has been called the discharge area, because it expresses the area of the aquifer filled by free-flowing water along the water table. Both parameters can vary during the emptying process, and they control the shape of the hydrograph on the semilogarithmic plot (Fiorillo, 2011).

A hydrograph as in curve 3 of Fig. 1b occurs when the area occupied by the water table decreases during draining, causing a reduction in the discharge area. This reduction can occur when the water table is drained by other springs at lower elevations, as occurs for the Bagno della Regina, or due to the hydrogeological setting of the catchment (see Fig. 8 in Fiorillo, 2011). The reduction of the discharge area can lead to no spring discharge during a dry period, and it characterizes the springs as drought-vulnerable. Hydrographs as in curve 2 of Fig. 1b occur when the effective porosity increases in depth inside the epiphreatic zone, causing an increase in the discharge area (see Fig. 5 in Fiorillo, 2011), as found by Equation (2) for the Caposele aquifer. These springs generally guarantee water during the long dry period in the Mediterranean areas and can be considered drought-resistant. For these springs, an 
increase in the water table area during the draining, given constant effective porosity, would also produce a similar effect, but it appears less likely, from a geometrical point of view, to justify an increase in the discharge area of about four times for Caposele Spring (Equations (2) and (4)). For this spring, the water level data of the P1 well have allowed us to investigate the hydraulic behavior of the aquifer during draining. It has been found that the ratio of the effective porosity evaluated by Equation (2) is very similar to that of Equation (4), verifying the hypothesis of Fiorillo's (2011) model.

These results indicate that a change in the effective porosity inside the epiphreatic zone has to be connected to different developments of caves, conduits, and voids that favor increasing water storage from a high to low water table. Numerical models have shown how mixing corrosion causes the development of conduits and porosity just below the water table of an unconfined aquifer (Gabrovšek and Dreybrodt, 2010; Dreybrodt et al., 2010). As a consequence, just below the water table there is a strong variation in void distribution (Fiorillo, 2011) that can be observed by the shape of curve 2 in Figure 1b. These hydraulic characteristics probably are more common in basal springs, where a saturated karst aquifer extends well below the spring elevation and the water table area remains constant during the emptying. In the case of aquifer behavior as curve 3 of Figure 1b, a change in the effective porosity inside the epiphreatic zone cannot be ascertained.

Our data and analyses suggest that the common and diffuse computation of the water stored into an karst aquifer obtained by integrating Equation (1), the Maillet equation, over the time interval $t_{0}$ to infinity, should be used with caution in the evaluation of the water resources, as no-homogenous hydraulic and geometric conditions may occur during the draining of an aquifer, especially under drought conditions.

\section{ACKNOWLEDGEMENTS}

The authors are grateful to Nico Goldscheider and to two anonymous reviewers for their helpful comments. Robert Brinkmann improved the latest version of the text, and Acquedotto Pugliese S.p.A. supported this study.

\section{REFERENCES}

Atkinson, T.C., 1977, Diffuse flow and conduit flow in limestone terrain in the Mendip Hills, Somerset (Great Britain): Journal of Hydrology, v. 35, p. 93-100. doi:10.1016/0022-1694(77)90079-8.

Bakalowicz, M., 2005, Karst groundwater: a challenge for new resources: Hydrogeology Journal, v. 13, p. 148-160. doi:10.1007/s10040-0040402-9.
Celico, P., and Civita, M., 1976, Sulla tettonica del massiccio del Cervialto (Campania) e le implicazioni idrogeologiche ad essa connesse: Bollettino della Società deiNaturalisti in Napoli, v. 85 .

Coppola, L., Cotecchia, V., Lattanzio, M., Salvemini, A., Tadolini, T., and Ventrella, N.A., 1989, Il gruppo di sorgenti di Cassano Irpino: regime idrologico ed analisi strutturale del bacino di alimentazione [The Cassano springs: hydrological regime and structural analysis of the catchment]: Geologia Applicata e Idrogeologia, v. 24, p. 227-260.

Criss, R.E., and Winston, W.E., 2003, Hydrograph for small basins following intense storms: Geophysical Research Letters, v. 30, no. 6, 1314 p. doi:10.1029/2002GL016808.

Dreybrodt, W., Romanov, D., and Kaufmann, G., 2010, Evolution of caves in porous limestone by mixing corrosion: a model approach: Geologia Croatica, v. 63, no. 2, p. 129-135.

Fiorillo, F., 2009, Spring hydrographs as indicators of droughts in a karst environment: Journal of Hydrology, v. 373, p. 290-301. doi:10.1016/ j.jhydrol.2009.04.034.

Fiorillo, F., 2011, Tank-reservoir drainage as a simulation of recession limb of karst spring hydrographs: Hydrogeology Journal, v. 19, p. 1009-1019. doi:10.1007/s10040-011-0737-y.

Fiorillo, F., Esposito, L., and Guadagno, F.M., 2007, Analyses and forecast of water resources in an ultra-centenarian spring discharge series from Serino (southern Italy): Journal of Hydrology, v. 336, p. 125-138. doi:10.1016/j.jhydrol.2006.12.016.

Fiorillo, F., and Doglioni, A., 2010, The relation between karst spring discharge and rainfall by cross-correlation analysis: Hydrogeology Journal, v. 18, p. 1881-1895. doi:10.1007/s10040-010-0666-1.

Fiorillo, F., and Guadagno, F.M., 2010, Karst spring discharges analysis in relation to drought periods, using the SPI: Water Resources Management, v. 24, p. 1867-1884. doi:10.1007/s11269-009-9528-9.

Ford, D., and Williams, P., 2007, Karst Hydrogeology and Geomorphology, Chichester, England, Wiley, 562 p.

Forkasiewicz, J., and Paloc, H., 1967, Le regime de tarissement de la Foux-de-la-Vis. Etude preliminaire: Chronique d'Hydrogeologie, BRGM, v. 3, no. 10, p. 61-73.

Gabrovšek, F., and Dreybrodt, W., 2010, Karstification in unconfined limestone aquifers by mixing of phreatic water with surface water from a local input: a model: Journal of Hydrology, v. 386, p. 130-141. doi:10.1016/j.jhydrol.2010.03.015.

Goldscheider, N., and Drew, D., eds., 2007, Methods in Karst Hydrogeology, London, Taylor \& Francis, International Contributions to Hydrogeology 26, $264 \mathrm{p}$.

Goldscheider, N., and Ravbar, N., 2010, Editorial: Research frontiers and practical challenges in karst hydrogeology: Acta Carsologica, v. 39, no. 2 , p. $169-172$.

ISPRA, 2009, Geological Map of Italy, 1:50.000 scale, Foglio n. 450 "S. Angelo dei Lombardi", Rome, Istituto Superiore per la Protezione e la Ricerca Ambientale.

Kovács, A., and Perrochet, P., 2008, A quantitative approach to spring hydrograph decomposition: Journal of Hydrology, v. 352, p. 16-29. doi:10.1016/j.jhydrol.2007.12.009.

Kovács, A., Perrochet, P., Király, L., and Jeannin, P.-Y., 2005, A quantitative method for characterisation of karst aquifers based on the spring hydrograph analysis: Journal of Hydrology, v. 303, p. 152-164. doi:10.1016/j.jhydrol.2004.08.023.

Mangin, A., 1975, Contribution à l'étude hydrodynamique des aquiféres karstiques: Troisieme partie: constitution et fonctionnement des aquifères karstiques: Annales de Spéléologie, v. 30, no. 1, p. 21-124.

Milanović, P., 1976, Water regime in deep karst: case study of Ombla Spring drainage area, in Yevjevich, V., ed., Karst Hydrology and Water Resources, Volume 1, Karst Hydrology, Fort Collins, Colorado, Water Resources Publications, p. 165-186.

Stevanovic, Z., Milanovic, S., and Ristic, V., 2010, Supportive methods for assessing effective porosity and regulating karst aquifers, Acta Carsologica, v. 39, no. 2, p. 313-329.

Thornthwaite, C.W., 1948, An approach towards a rational classification of climate: Geographical Review, v. 38, p. 55-94.

White, W.B., 1988, Geomorphology and Hydrology of Karst Terrains, New York, Oxford University Press, 464 p. 